\title{
Antioxidant and free radical scavenging activities of wild bitter melon (Momordica charantia Linn. var. abbreviata Ser.) in Taiwan
}

\author{
Shu-Jing $\mathrm{Wu}^{\mathrm{a}}$, Lean-Teik $\mathrm{Ng}^{\mathrm{b}, *}$ \\ ${ }^{a}$ Department of Health and Nutrition, Chia-Nan University of Pharmacy and Technology, Tainan, Taiwan \\ ${ }^{\mathrm{b}}$ Department of Biotechnology, Tajen University, No. 20 Weishin Road, Yanpu Shiang, Pingtung, Taiwan
}

Received 16 August 2006; received in revised form 9 March 2007; accepted 12 March 2007

\begin{abstract}
Momordica charantia Linn. var. abbreviata Ser. (Cucurbitaceae), also known as "Shan Ku Gua", is a wild variety of bitter melon (BM) in Taiwan. The size of its fruits is only about one-fifth of the commonly seen BM. It is commonly consumed as vegetable and also used as a popular folk medicine. In this study, the antioxidant and free radical scavenging activities of $\mathrm{BM}$ aqueous $\left(\mathrm{BM}-\mathrm{H}_{2} \mathrm{O}\right)$ and ethanol $(\mathrm{BM}-$ EtOH) extracts were evaluated using 2,2-diphenyl-1-picrylhydrazyl (DPPH), metal chelation, cytochrome $c$ and xanthine oxidase inhibition (XOI) assays, as well as $\mathrm{FeCl}_{2}$-ascorbic acid induced lipid peroxidation (thiobarbituric acid reactive substances, TBARS) assay in rat liver homogenates in vitro. Total flavonoid and phenol contents of BM extracts were also analyzed. Results showed that both BM$\mathrm{H}_{2} \mathrm{O}\left(\mathrm{IC}_{50}=129.94 \mu \mathrm{g} / \mathrm{ml}\right)$ and BM-EtOH $\left(\mathrm{IC}_{50}=156.78 \mu \mathrm{g} / \mathrm{ml}\right)$ possess potent DPPH radical scavenging activity, which was better than vitamin $\mathrm{E}\left(\mathrm{IC}_{50}=172.21 \mu \mathrm{g} / \mathrm{ml}\right)$. These extracts also showed better iron chelating activity than vitamin E. However, they were weaker than vitamin $\mathrm{E}$ in free radical scavenging, xanthine oxidase inhibitory and anti-lipid peroxidation activities. With the exception of XOI activity $\left[\mathrm{IC}_{50}=7.90 \mu \mathrm{g} / \mathrm{ml}\left(\mathrm{BM}-\mathrm{H}_{2} \mathrm{O}\right)\right.$ vs. $\left.7.69 \mu \mathrm{g} / \mathrm{ml}(\mathrm{BM}-\mathrm{EtOH})\right], \mathrm{BM}-\mathrm{H}_{2} \mathrm{O}$ showed a lower $\mathrm{IC}_{50}$ value in free radical scavenging $\left[\mathrm{IC}_{50}=6.15 \mu \mathrm{g} / \mathrm{ml}\left(\mathrm{BM}-\mathrm{H}_{2} \mathrm{O}\right)\right.$ vs. $\left.7.08 \mu \mathrm{g} / \mathrm{ml}(\mathrm{BM}-\mathrm{EtOH})\right]$ and anti-lipid peroxidation $\left[\mathrm{IC}_{50}=53.72 \mu \mathrm{g} / \mathrm{ml}\left(\mathrm{BM}-\mathrm{H}_{2} \mathrm{O}\right) \mathrm{vs} .88 .51 \mu \mathrm{g} / \mathrm{ml}\right.$ (BM-EtOH) for liver; $82.53 \mu \mathrm{g} / \mathrm{ml}\left(\mathrm{BM}-\mathrm{H}_{2} \mathrm{O}\right)$ vs. $91.83 \mu \mathrm{g} / \mathrm{ml}(\mathrm{BM}-\mathrm{EtOH})$ for brain] activities than BM-EtOH. Both BM extracts showed a weak anti-lipid peroxidation activity in plasma. $\mathrm{BM}-\mathrm{H}_{2} \mathrm{O}(62.0 \mathrm{mg} / \mathrm{g})$ possessed a significant higher concentration of total flavonoids than BM-EtOH $(44.0 \mathrm{mg} / \mathrm{g})$, but was lower in the total phenol content $\left(\mathrm{BM}-\mathrm{H}_{2} \mathrm{O}: 51.6 \mathrm{mg} / \mathrm{g}\right.$ vs. BM-EtOH: $\left.68.8 \mathrm{mg} / \mathrm{g}\right)$. In conclusion, $\mathrm{BM}$ extracts possess potent antioxidant and free radical scavenging activities. These antioxidant activities could have contributed, at least partly, to the therapeutic benefits of the certain traditional claims of wild BM.
\end{abstract}

(C) 2007 Swiss Society of Food Science and Technology. Published by Elsevier Ltd. All rights reserved.

Keywords: Momordica charantia; Wild bitter melon; Antioxidant; Free radical scavenging

\section{Introduction}

Free radicals are known to be the major cause of various chronic and degenerative diseases, including aging, coronary heart disease, inflammation, stroke, diabetes mellitus and cancer (Cheng, Lin, Yu, Yang, \& Lin, 2003; Slater, 1984). Reactive oxygen species (ROS) include free radicals such as ${ }^{\circ} \mathrm{O}_{2}^{-}$(superoxide anion), ${ }^{\circ} \mathrm{OH}$ (hydroxyl radical), $\mathrm{H}_{2} \mathrm{O}_{2}$ (hydrogen peroxide) and ${ }^{1} \mathrm{O}_{2}$ (singlet oxygen) can cause cellular injuries and initiate peroxidation of poly-

\footnotetext{
*Corresponding author. Tel.: +88687624002x450; fax: +88687621645 .

E-mail address: 1thuang@mail.tajen.edu.tw (L.T. Ng).
}

unsaturated fatty acids in biological membranes (Compori, 1985; Halliwell, 1997). The tissue injury caused by ROS may include DNA damage (Halliwell, 1997; Halliwell \& Gutteridge, 1984), protein damage (Bartold, Wiebkin, \& Thonard, 1984), and oxidation of important enzymes (Varani et al., 1985) in the human body. These events could consequently lead to the occurrence of various freeradical-related diseases. Recently, natural foods and foodderived antioxidants such as vitamins and phenolic phytochemicals have received growing attention, because they are known to function as chemopreventive agents against oxidative damage.

The plant Momordica charantia Linn. var. abbreviata Ser. (Cucurbitaceae), a wild variety of bitter melon (BM), is 
commonly found growing in wilds around the farmlands in Taiwan. It is known locally as "Shan Ku Gua". The size of its fruits is only about one-fifth of the commonly seen BM. Currently the wild BM fruits sold in the market are mainly collected from the wild. They are often used to prepare health beverages and consumed as vegetable.

Previous studies have shown that extracts of wild BM fruits suppressed lymphocyte proliferation, and macrophage and lymphocyte activity (Chao \& Huang, 2003). Traditionally, the wild BM leaves are crushed to obtain the juice for applying on the skin for treating insect bites, bee stings, burns, contact rashes, and wounds. Decoction of its leaves and fruits is drunk as preventative or treatment of stomachache, toothache, liver diseases, diabetes, hypertension and cancer (Chiu \& Chang, 1995). Fruits of wild BM are believed to be more effective in treating diabetes than the commonly seen BM.

At present, scientific information reported on chemical and biological properties of wild BM remains limited. From the literatures, BM is known to contain compounds such as momorcharins, momordenol, momordicilin, momordicins, momordicinin, momordin, momordolol, charantin, charine, cryptoxanthin, cucurbitins, cucurbitacins, cucurbitanes, cycloartenols, diosgenin, elaeostearic acids, erythrodiol, galacturonic acids, gentisic acid, goyaglycosides and goyasaponins (Grover \& Yadav, 2004), caffeic acid and ferulic acid (Raj, Khan, Singh, Kumari, \& Prakash, 2005), fisetin and isorhamnetin (Lako et al., 2007), $\quad 3 \beta, 25$-dihydroxy-7 $\beta$-methoxycucurbita-5,23(E)diene, 3 3 -hydroxy-7,25-dimethoxycucurbita-5,23(E)-diene and $\quad 3-O-\beta$-D-allopyranosyl-7 $\beta, 25$-dihydroxycucurbita5,23(E)-dien-19-al (Harinantenaina et al., 2006). Its MAP30 protein exhibited anti-HIV and anti-tumor activities (Lee-Huang et al., 1995), momorcharins and momordins showed activities in inactivating ribosomes, momordin 1c and oleanolic acid glycoside in altering gastrointestinal transit time and blood glucose (Chao \& Huang, 2003; Grover \& Yadav, 2004).

Although wild BM has been widely used as health foods and folk medicine, it remains unknown if certain therapeutic claims of either the aqueous or ethanolic extract of wild BM are derived from its antioxidant activities. In this study, our aim was to examine the antioxidant and free radical scavenging activities of different wild BM extracts prepared according to the traditional food and medical practice. Its total flavonoid and phenol contents were also determined.

\section{Materials and methods}

\subsection{Chemicals}

L- $(+)$-ascorbic acid, thiobarbituric acid (TBA), xanthine, xanthine oxidase and cytochrome $c$ were purchased from Sigma Chemical Co. (St. Louis, MO, USA). Vitamin E ( $\alpha$-tocopherol), dimethylsulphoxide (DMSO) and ferrous chloride were obtained from Wako
Pure Chemical Industries (Osaka, Japan). All other chemicals used were of analytical grade.

\subsection{Plant materials}

The BM materials were collected from the wild and authenticated by Dr. K.T. Cheng, Taipei Medical University, Taiwan. They were cut into pieces, dried and then ground to powdered-form, which was then kept in an airtight plastic bag until use.

\subsection{Preparation of extracts}

The aqueous BM extract was prepared by extracting $100 \mathrm{~g}$ of $\mathrm{BM}$ powder with $11 \mathrm{of}$ boiling water for $1 \mathrm{~h}$. The extract was filtered with filter paper (Advantec No. 1, Japan), the residue was then re-extracted under the same conditions twice. The filtrates were combined, concentrated and lyophilized. For the ethanol extract, it was prepared by soaking $100 \mathrm{~g}$ of BM powder with 11 of ethanol $(95 \%)$ at room temperature for 6 days. After filtering the extract with filter paper (Advantec No. 1, Japan), the filtrate collected was concentrated and lyophilized. The dried powdered-extract was stored at $4{ }^{\circ} \mathrm{C}$ until use. The average yield obtained for aqueous $\mathrm{BM}$ extract $\left(\mathrm{BM}-\mathrm{H}_{2} \mathrm{O}\right)$ and ethanol BM extract (BM-EtOH) was about $31 \%$ and $22 \%$, respectively.

\subsection{Plasma, liver and brain homogenate preparation}

Male Sprague-Dawley rats, weighing about 200 g, were sacrificed under ether anesthesia. After obtaining the blood by cardiac puncture, about $2 \mathrm{~g}$ of liver and brain tissues were removed and sliced into pieces. The tissue samples were homogenized with $10 \mathrm{ml}$ of $150 \mathrm{mmol} / 1 \mathrm{KCl}-\mathrm{Tris}-\mathrm{HCl}$ buffer ( $\mathrm{pH} 7.2$ ), and then centrifuged at $500 \mathrm{~g}$ for $10 \mathrm{~min}$ to give a supernatant of liver or brain homogenate. The supernatant was collected and its protein content was determined by the method of Lowry, Rosebrough, Farr, and Randall (1951). Blood was centrifuged at $1000 \mathrm{~g}$ at $4{ }^{\circ} \mathrm{C}$ for $15 \mathrm{~min}$ to obtain a supernatant layer of plasma, which was collected and stored at $-80^{\circ} \mathrm{C}$ until analysis.

\section{5. $D P P H$ radical scavenging activity}

DPPH radical scavenging activity was determined according to the methods of Blois (1958), Chang, Lee, and $\mathrm{Ng}$ (2006). Briefly, $1 \mathrm{ml}$ of $0.1 \mathrm{mmol} / \mathrm{l} \mathrm{DPPH}$ radical solution was mixed with $3 \mathrm{ml}$ of various concentrations of extract $(50,100$, and $300 \mu \mathrm{g} / \mathrm{ml})$ dissolving in methanol. The mixture was then vortexed vigorously and left for $30 \mathrm{~min}$ at $40{ }^{\circ} \mathrm{C}$ in the dark. For the baseline control, $3 \mathrm{ml}$ of methanol was used. The absorbance was measured at $517 \mathrm{~nm}$. 


\subsection{Metal chelating activity}

The chelation of ferrous ions by the extract was estimated by the method of Dinis, Madeira, and Almeida (1994) with modifications. In brief, $1 \mathrm{ml}$ of extract at different concentrations $(1,10$, and $100 \mu \mathrm{g} / \mathrm{ml})$ was mixed with $3.7 \mathrm{ml}$ of methanol and $0.1 \mathrm{ml}$ of $1 \mathrm{mmol} / 1 \mathrm{FeCl}_{2}$. The reaction was initiated by the addition of $0.2 \mathrm{ml}$ of $5 \mathrm{mmol} / 1$ ferrozine, followed by shaking vigorously and left to react at room temperature for $10 \mathrm{~min}$. The absorbance was measured spectrophotometrically at $562 \mathrm{~nm}$.

\subsection{Free radical scavenging activity assay}

Free radical scavenging activity was assayed spectrophotometrically by the reduction of cytochrome $c$ method as described by McCord and Fridovich (1969). In brief, $10 \mathrm{mg}$ of BM extracts or vitamin $\mathrm{E}$ was dissolved in DMSO and further diluted with $50 \mathrm{mmol} / 1$ phosphate buffer $(\mathrm{pH}=7.8)$ to various concentrations $(1,10$, and $100 \mu \mathrm{g} /$ $\mathrm{ml}$ ), then $20 \mu \mathrm{l}$ of $0.07 \mathrm{units} / \mathrm{ml}$ xanthine oxidase, $300 \mu \mathrm{l}$ of $100 \mu \mathrm{mol} / 1$ xanthine and $15 \mu \mathrm{l}$ of $50 \mu \mathrm{mol} / 1$ cytochrome $c$ were added to these samples. They were vigorously mixed and then incubated for $3 \mathrm{~min}$ at room temperature, followed by spectrophotometric determination of the ferricytochrome $c$ reduction at $550 \mathrm{~nm}$.

\subsection{Xanthine oxidase inhibition (XOI) test}

XOI activity was estimated by the formation of uric acid from xanthine-xanthine oxidase system (Chang, Chang, $\mathrm{Lu}$, \& Chiang, 1994). Test samples were dissolved in DMSO, and then diluted with $50 \mathrm{mmol} / 1$ phosphate buffer $(\mathrm{pH}=7.8)$ to various concentrations $(1,10$, and $100 \mu \mathrm{g} /$ $\mathrm{ml})$. After $350 \mu \mathrm{l}$ of xanthine $(100 \mu \mathrm{mol} / \mathrm{l})$ and $20 \mu \mathrm{l}$ of xanthine oxidase ( 0.4 units) were added, samples were vigorously mixed and then incubated for $3 \mathrm{~min}$ at room temperature. Superoxide formation was counted by spectrophotometric measurement of uric acid production at $295 \mathrm{~nm}$.

\subsection{Anti-lipid peroxidation assay}

The effect of $\mathrm{BM}$ extracts on $\mathrm{FeCl}_{2}$-ascorbic acid induced lipid peroxidation in rat liver and brain homogenates, and plasma was determined by the method of Yoshiyuki, Michinori, Tadato, Shigeru, and Hiromichi (1981). In brief, a reaction mixture containing $0.5 \mathrm{ml}$ of liver or brain homogenate or plasma sample, $0.1 \mathrm{ml}$ of Tris- $\mathrm{HCl}$ buffer $(\mathrm{pH}=7.2), 0.05 \mathrm{ml}$ of $0.1 \mathrm{mmol} / 1$ ascorbic acid, $0.05 \mathrm{ml}$ of $4 \mathrm{mmol} / 1 \mathrm{FeCl}_{2}$, and $0.05 \mathrm{ml}$ of various concentrations of $\mathrm{BM}$ extracts or vitamin $\mathrm{E}$ was mixed in a capped tube and then incubated for $1 \mathrm{~h}$ at $37^{\circ} \mathrm{C}$. After incubation, $0.9 \mathrm{ml}$ of distilled water and $2 \mathrm{ml}$ of $0.6 \%$ TBA were added and then shaken vigorously. The mixture was heated for $30 \mathrm{~min}$ in a boiling water bath at $100^{\circ} \mathrm{C}$. After cooling, $5 \mathrm{ml}$ of $n$-butanol was added and the mixture was then shaken vigorously. The $n$-butanol layer was separated by centrifugation at $3000 \mathrm{~g}$ for $10 \mathrm{~min}$, followed by subjecting to the measurement of TBA reactive substances (TBARS) production at $532 \mathrm{~nm}$.

\subsection{Total flavonoid analysis}

The total flavonoid content of wild BM was determined according to colorimetric method as described by Zou, Lu, and Wei (2004). In brief, $0.5 \mathrm{ml}$ of sample solution was mixed with $2 \mathrm{ml}$ of distilled water and subsequently with $0.15 \mathrm{ml}$ of $5 \% \mathrm{NaNO}_{2}$ solution. After $6 \mathrm{~min}$ of incubation, $0.15 \mathrm{ml}$ of $10 \% \mathrm{AlCl}_{3}$ solution was added and then allowed to stand for $6 \mathrm{~min}$, followed by adding $2 \mathrm{ml}$ of $4 \% \mathrm{NaOH}$ solution to the mixture. Immediately after water was added to the sample to bring the final volume to $5 \mathrm{ml}$, the mixture was thoroughly mixed and allowed to stand for another $15 \mathrm{~min}$. The mixture absorbance was determined at wavelength $510 \mathrm{~nm}$. The total flavonoid content was expressed in milligrams of rutin equivalents per gram of BM extract.

\subsection{Total phenol analysis}

The total phenol content of wild BM was analyzed according to the Folin-Ciocalteu method as described by Cliffe, Fawer, Maier, Takata, and Ritter (1994). In brief, after BM extracts were well mixed with $2.5 \mathrm{ml}$ of distilled water, $0.5 \mathrm{ml}$ of the Folin-Ciocalteu stock reagent and $1.0 \mathrm{ml}$ of $\mathrm{Na}_{2} \mathrm{CO}_{3}$ reagent $(75 \mathrm{~g} / 1)$ were added to the mixture. They were then incubated at room temperature for $30 \mathrm{~min}$. The mixture absorbance was spectrophotometrically measured at wavelength $765 \mathrm{~nm}$. The total phenol content was expressed in milligrams of gallic acid equivalents per gram of BM extract.

\subsection{Statistical analysis}

Data were presented as means \pm standard deviations (SD) from three independent analyzes. Results were evaluated by one-way ANOVA, followed by Duncan's multiple range tests. Total flavonoid and phenol contents between $\mathrm{BM}-\mathrm{H}_{2} \mathrm{O}$ and $\mathrm{BM}-\mathrm{EtOH}$ were compared using Student's $t$-test. Difference was considered significant when $P$-value was $<0.05$.

\section{Results and discussion}

\subsection{DPPH radical scavenging activity}

Results showed that both $\mathrm{BM}-\mathrm{H}_{2} \mathrm{O}$ and $\mathrm{BM}-\mathrm{EtOH}$ were effective in reducing the stable radical DPPH to the yellowcolored diphenylpicrylhydrazine, indicating that these extracts are active in DPPH radical scavenging (Fig. 1). $\mathrm{BM}-\mathrm{H}_{2} \mathrm{O}\left(\mathrm{IC}_{50}=129.94 \mu \mathrm{g} / \mathrm{ml}\right)$ demonstrated a stronger DPPH radical scavenging activity than BM-EtOH $\left(\mathrm{IC}_{50}=156.78 \mu \mathrm{g} / \mathrm{ml}\right)($ Table 1). Interestingly, these BM 
extracts showed a stronger scavenging activity than vitamin $\mathrm{E}\left(\mathrm{IC}_{50}=172.21 \mu \mathrm{g} / \mathrm{ml}\right)$, suggesting that both $\mathrm{BM}$ extracts possess potent free radical scavenging activity.

\subsection{Metal chelating activity}

Ferrozine can quantitatively form complexes with $\mathrm{Fe}^{2+}$. In the presence of other chelating agents, the complex formation is disrupted with the result that the red color of the complex is decreased. Measurement of the rate of color reduction therefore allows estimation of the chelating activity of the coexisting chelator (Yamaguchi, Ariga, Yoshimira, \& Nakazawa, 2000). In this study, both BM extracts and vitamin E showed chelating activity as demonstrated by their effectiveness in inhibiting the formation of ferrous and ferrozine complex (Fig. 2). The absorbance of $\mathrm{Fe}^{2+}$-ferrozine complex was dose dependently decreased from 100 to $500 \mu \mathrm{g} / \mathrm{ml}$ for both BM extracts and vitamin E. Although the iron chelating ability of $\mathrm{BM}$ extracts was moderate, they were stronger than vitamin $\mathrm{E}$ (Table 1). Chelating agents, which form $\sigma$-bonds with a metal, are effective as secondary antioxidants

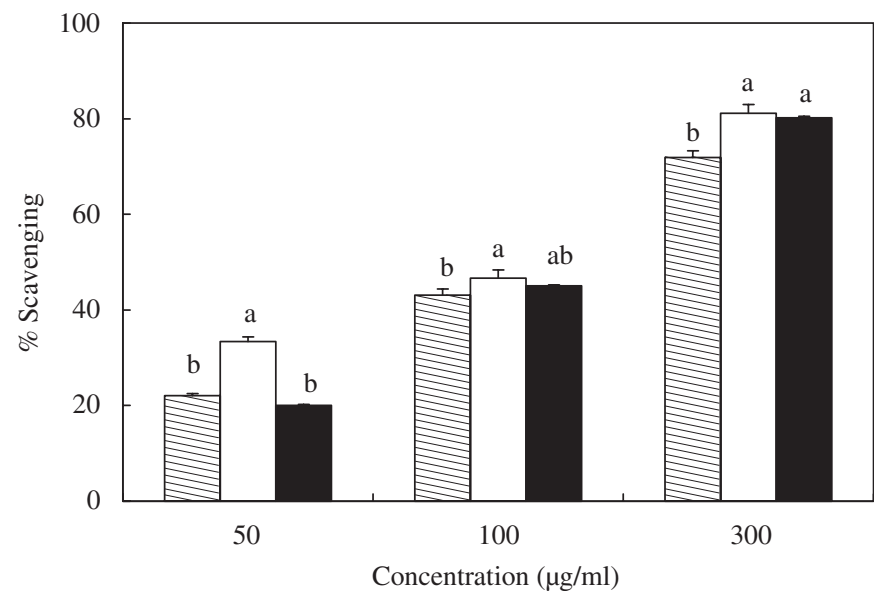

Fig. 1. DPPH radical scavenging activity of different wild bitter melon extracts (aqueous: $\mathrm{BM}-\mathrm{H}_{2} \mathrm{O}$ and ethanol: $\mathrm{BM}-\mathrm{EtOH}$ ). Data were presented as the percentage of DPPH radical scavenging, means \pm SD $(n=3)$; values within the same concentration with the different superscript letters were significantly different at $P<0.05$ as analyzed by Duncan's multiple range tests. $\mathbb{\mathbb { }}$, Vit E; $\square, \mathrm{BM}-\mathrm{H}_{2} \mathrm{O} ; \mathbf{\square}, \mathrm{BM}-\mathrm{EtOH}$. because they reduce the redox potential thereby stabilizing the oxidized form of the metal ion (Gordon, 1990). Extracts or compounds with chelating activity are believed to inhibit lipid peroxidation by stabilizing transition metals.

\subsection{Free radical scavenging activity}

The results on the effect of different concentrations of wild BM extracts on superoxide anions are shown in Fig. 3. The superoxide scavenging effect was found to increase with increasing concentration of BM extracts regardless of the nature of preparation. At concentrations $1-100 \mu \mathrm{g} / \mathrm{ml}$, $\mathrm{BM}$ extracts showed a scavenging rate ranging from $36.6 \%$ to $75.8 \%$ for $\mathrm{BM}-\mathrm{H}_{2} \mathrm{O}$, and $28.1 \%$ to $71.1 \%$ for $\mathrm{BM}$ EtOH. Although both $\mathrm{BM}-\mathrm{H}_{2} \mathrm{O}$ and $\mathrm{BM}-\mathrm{EtOH}$ exhibited a lower superoxide scavenging activity than vitamin $\mathrm{E}$, they possess a relatively close $\mathrm{IC}_{50}$ values $(6.15 \mu \mathrm{g} / \mathrm{ml}$ for $\mathrm{BM}-\mathrm{H}_{2} \mathrm{O}$ and $7.08 \mu \mathrm{g} / \mathrm{ml}$ for BM-EtOH) (Table 1).

The scavenging action of plant constituents has been found to relate to polyphenolic compounds (Hatono et al., 1989; Kimura, Okuda, Hatono, Agata, \& Arichi, 1985), to

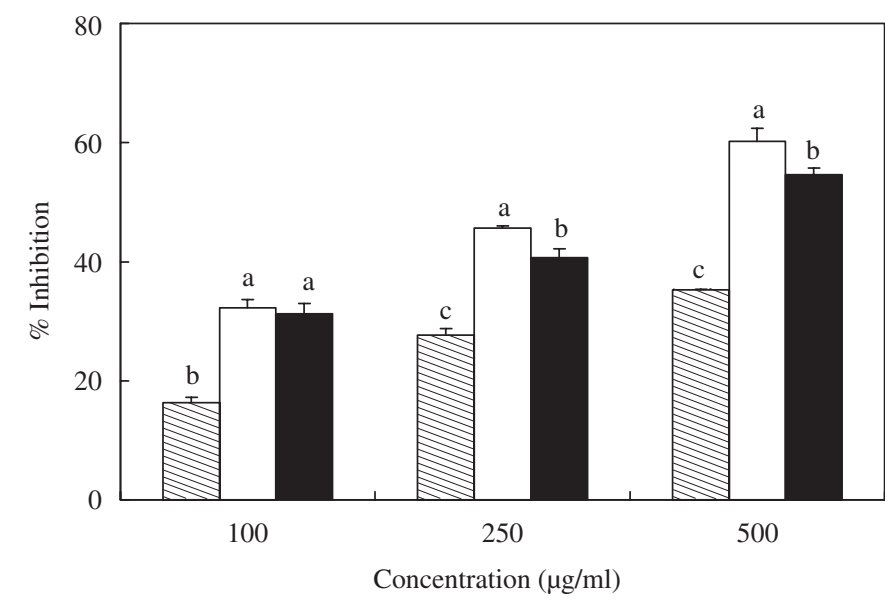

Fig. 2. Metal chelating activity of different wild bitter melon extracts (aqueous: $\mathrm{BM}-\mathrm{H}_{2} \mathrm{O}$ and ethanol: $\mathrm{BM}-\mathrm{EtOH}$ ). Data were presented as the percentage of inhibition on metal chelation, means $\pm \operatorname{SD}(n=3)$; values within the same concentration with the different superscript letters were significantly different at $P<0.05$ as analyzed by Duncan's multiple range tests. $\mathbb{Q}$, Vit E; $\square$, BM- $\mathrm{H}_{2} \mathrm{O} ; \mathbf{\square}$, BM-EtOH.

Table 1

$\mathrm{IC}_{50}$ values of antioxidant activities of different wild bitter melon extracts

\begin{tabular}{lllllrr}
\hline Samples & \multicolumn{2}{l}{$\mathrm{IC}_{50}$ values $(\mu \mathrm{g} / \mathrm{ml})$} & & & \\
\cline { 2 - 7 } & DPPH & Metal chelation & Cytochrome $c$ & XOI & \multicolumn{2}{c}{ Anti-lipid peroxid } \\
\cline { 3 - 7 } & & & & & Liver & Brain \\
\hline BM- $\mathrm{H}_{2} \mathrm{O}$ & 129.94 & 340.18 & 6.15 & 7.90 & 53.72 & 82.53 \\
BM-EtOH & 156.78 & 416.99 & 7.08 & 7.69 & 88.51 & 91.83 \\
Vitamin E & 172.21 & 477.52 & 0.18 & 0.79 & 3.00 & 5.42 \\
\hline
\end{tabular}




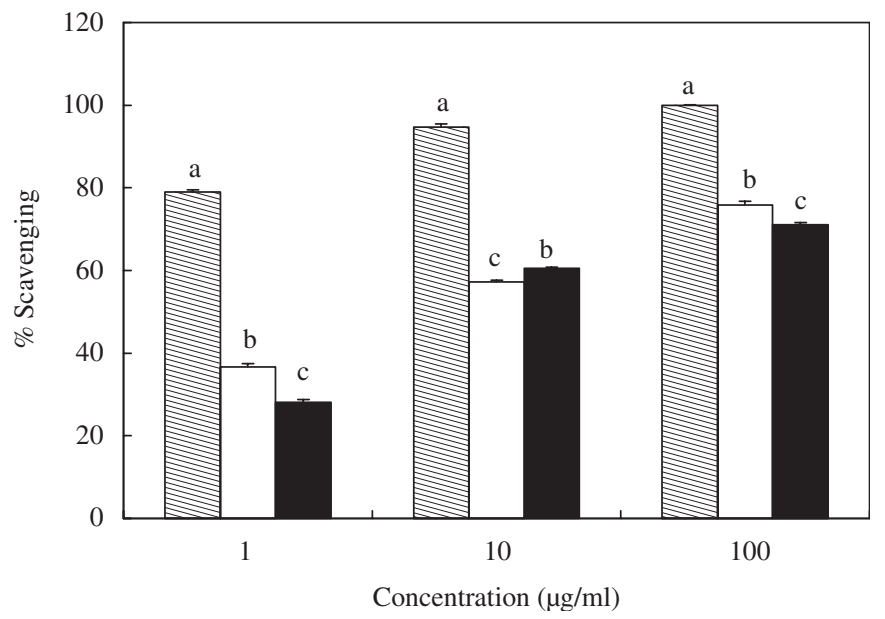

Fig. 3. Free radical scavenging activity of different wild bitter melon extracts (aqueous: $\mathrm{BM}-\mathrm{H}_{2} \mathrm{O}$ and ethanol: $\mathrm{BM}-\mathrm{EtOH}$ ). Data were presented as the percentage of free radical scavenging, means $\pm S D$ $(n=3)$; values within the same concentration with the different superscript letters were significantly different at $P<0.05$ as analyzed by Duncan's multiple range tests. $\mathbb{\mathbb { N }}$, Vit E; $\square, \mathrm{BM}-\mathrm{H}_{2} \mathrm{O} ; \mathbf{\square}, \mathrm{BM}-\mathrm{EtOH}$.

caffeic acid derivatives (Kimura et al., 1985) and to flavonoids (Hatono et al., 1989). Although the constituents of BM, which show free radical scavenging action is still unclear, it is possible that the antioxidative properties of BM are caused, at least in part, by the presence of polyphenols and other yet to be discovered antioxidant compounds.

\subsection{XOI activity}

Both $\mathrm{BM}-\mathrm{H}_{2} \mathrm{O}$ and $\mathrm{BM}-\mathrm{EtOH}$ exhibited an inhibitory effect on xanthine oxidase activity in a concentrationdependent manner (Fig. 4). At concentrations $1-100 \mu \mathrm{g} / \mathrm{ml}$, the xanthine oxidase inhibitory activity varies from $26.9 \%$ to $66.7 \%$ for $\mathrm{BM}-\mathrm{H}_{2} \mathrm{O}$ and $28.6 \%$ to $77.8 \%$ for BM-EtOH. The $\mathrm{IC}_{50}$ value of $\mathrm{BM}-\mathrm{H}_{2} \mathrm{O}$ and $\mathrm{BM}-\mathrm{EtOH}$ was 7.90 and $7.69 \mu \mathrm{g} / \mathrm{ml}$, respectively (Table 1 ).

Xanthine oxidase is a flavoprotein, which catalyses the oxidation of hypoxanthine to xanthine and generates superoxide and uric acid (Cheng et al., 2003). Studies have shown that xanthine oxidase inhibitors may be useful for the treatment of hepatic disease and gout, which is caused by the generation of uric acid and superoxide anion radical (Lin, Hsu, \& Lin, 2001). Xanthine oxidase-derived superoxide anion has been linked to post-ischaemic tissue injury and edema (Hearse, Manning, Downey, \& Yellon, 1986; McCord \& Fridovich, 1969). Hence, phytochemicals or extracts such as BM extracts, which inhibit the superoxide anion regeneration by the enzymatic pathway would be beneficial in preventing ischaemia and edema.

\subsection{Anti-lipid peroxidation activity}

The inhibitory effect of BM extracts and vitamin E on TBARS production in rat liver and brain homogenates,

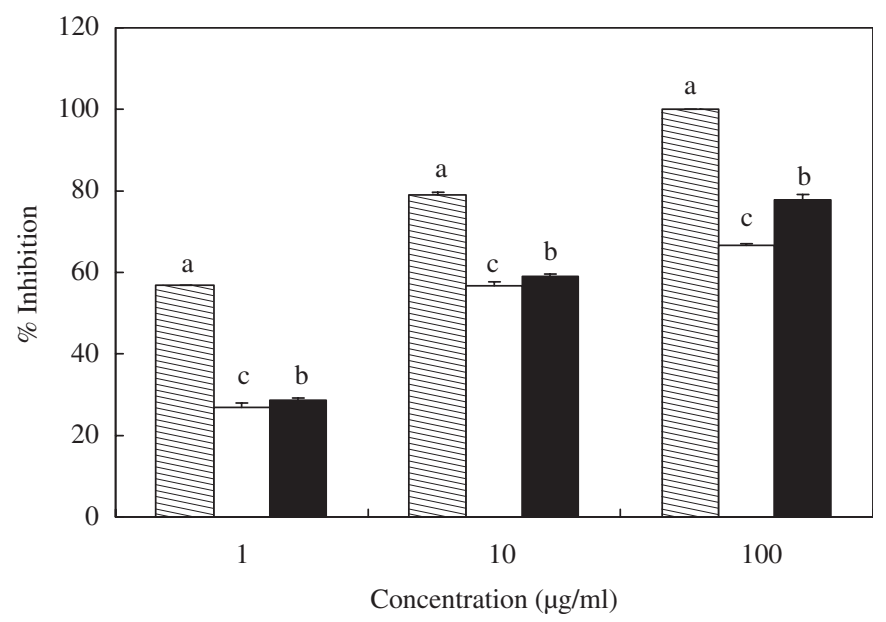

Fig. 4. Xanthine oxidase inhibition activity of different wild bitter melon extracts (aqueous: $\mathrm{BM}-\mathrm{H}_{2} \mathrm{O}$ and ethanol: BM-EtOH). Data were presented as the percentage of inhibition on the xanthine oxidase activity, means $\pm \mathrm{SD}(n=3)$; values within the same concentration with the different superscript letters were significantly different at $P<0.05$ as analyzed by Duncan's multiple range tests. $\mathbb{\mathbb { }}$, Vit E; $\square$, BM- $\mathrm{H}_{2} \mathrm{O} ; \mathbf{\square}$, BM-EtOH.

and plasma induced by $\mathrm{FeCl}_{2}$-ascorbic acid is shown in Fig. 5A-C. Results showed that the inhibition of TBARS formation increased with increasing concentrations of BM extracts and vitamin $\mathrm{E}$ in all tissues tested. At concentrations $10-500 \mu \mathrm{g} / \mathrm{ml}$, both $\mathrm{BM}-\mathrm{H}_{2} \mathrm{O}$ and $\mathrm{BM}-\mathrm{EtOH}$ displayed a different potency of anti-lipid peroxidation activity, with an inhibition rate for $\mathrm{BM}-\mathrm{H}_{2} \mathrm{O}$ varies from $32.4 \%$ to $76.1 \%$ for liver, $21.2 \%$ to $77.7 \%$ for brain and $5.3 \%$ to $30.5 \%$ for plasma, and for BM-EtOH ranges from $22.8 \%$ to $69.6 \%$ for liver, $25.9 \%$ to $75.4 \%$ for brain, and $19.0 \%$ to $35.8 \%$ for plasma. The anti-lipid peroxidation activity of both $\mathrm{BM}-\mathrm{H}_{2} \mathrm{O}$ and $\mathrm{BM}-\mathrm{EtOH}$ on plasma was moderate, with $\mathrm{IC}_{50}$ values greater than $500 \mu \mathrm{g} / \mathrm{ml}$ (Table 1).

Lipid peroxidation in biological systems has long been thought to be a toxicological phenomenon that can lead to various pathological consequences (Hochstein \& Atallah, 1988). $\mathrm{Fe}^{2+}$-ascorbic acid mixture is well known to stimulate lipid peroxidation in rat liver in vivo, and in microsome and mitochondria of rat liver in vitro (Kimuya, Kubo, Tani, Arich, \& Okuda, 1981; Kornbrust \& Mavis, 1980). Malondialdehyde (MDA) is very reactive and takes part in cross-linking with DNA and proteins, and also damages liver cells (Kubow, 1990). In China and Taiwan, certain health foods and crude drugs, their therapeutic benefits were believed to be derived from antioxidant activities (Cheng et al., 2003; Ichikawa \& Konishi, 2002; Lin, Ng, Yang, \& Hsu, 2004). In this study, BM- $\mathrm{H}_{2} \mathrm{O}$ exhibited a better antioxidant action than BM-EtOH in the rat homogenate model system, suggesting that $\mathrm{BM}-\mathrm{H}_{2} \mathrm{O}$ possesses a better cell membrane protection against biological lipid proxidation than BM-EtOH.

An increase in oxidative stress is widely accepted as one of the main factors involving in the development of 

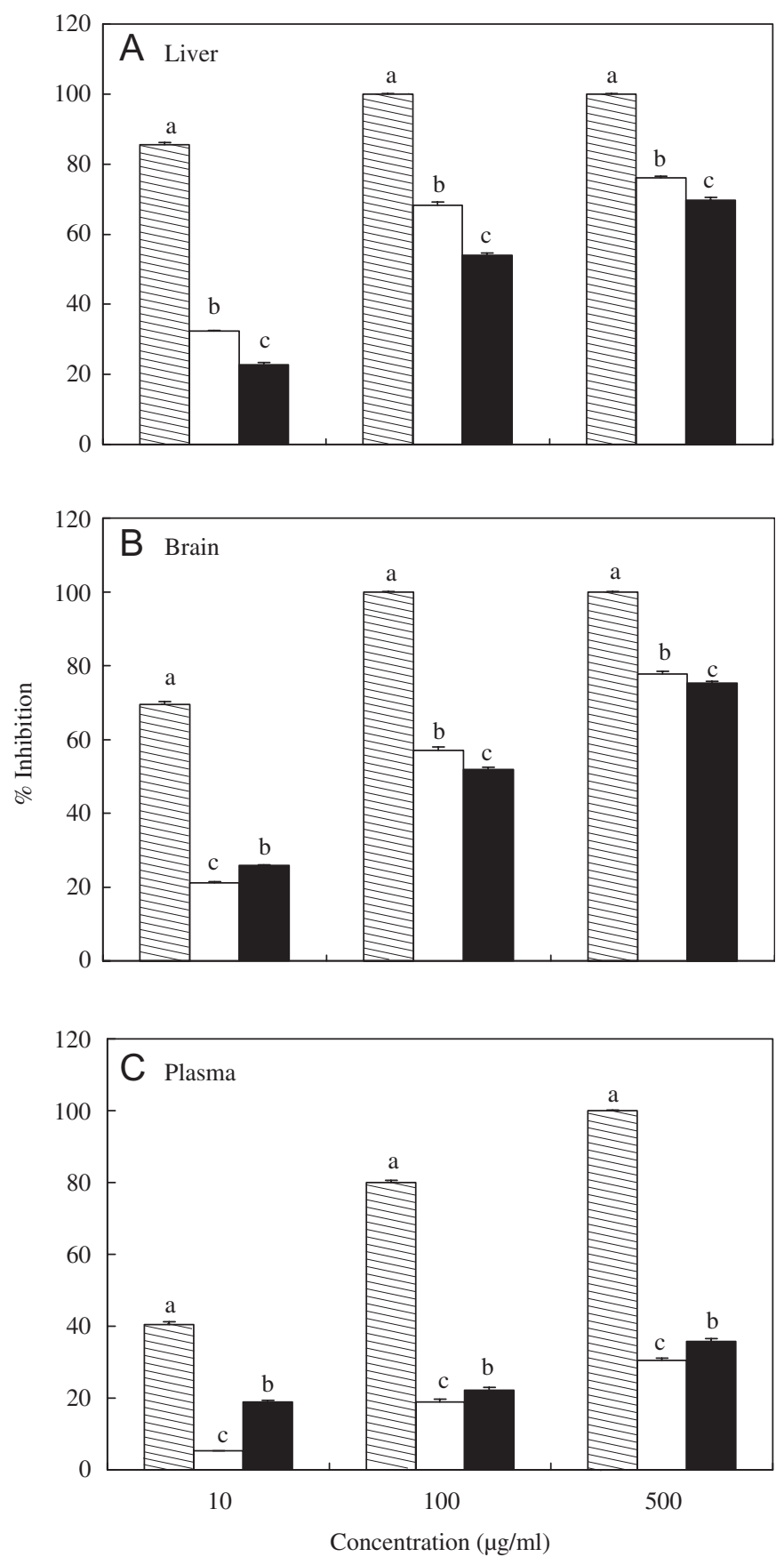

Fig. 5. Inhibitory effect of different wild bitter melon extracts (aqueous: BM- $\mathrm{H}_{2} \mathrm{O}$ and ethanol: $\left.\mathrm{BM}-\mathrm{EtOH}\right)$ on $\mathrm{FeCl}_{2}$-ascorbic acid induced lipid peroxidation in different rat tissues; (A) liver, (B) brain, and (C) plasma. Data were presented as the percentage of inhibition on the lipid peroxidation, means $\pm \mathrm{SD}(n=5)$; values within the same concentration with the different superscript letters were significantly different at $P<0.05$

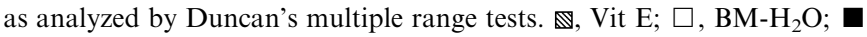
BM-EtOH.

diabetic complications (Baynes \& Thorpe, 1999; Ceriello, 2000). Diabetes mellitus is also reported to be associated with an increased production of free radicals (Baynes \& Thorpe, 1999). The majority of these free radicals and toxic molecules are derived from oxygen. The principal free radicals are superoxide $\left(\mathrm{O}_{2}^{*}\right)$, hydroxyl $\left({ }^{\circ} \mathrm{OH}\right)$ and peroxyl
$\left(\mathrm{LOO}^{\circ}\right)$ radicals, all of which may play a role in DNA damage, glycation, and protein modification reactions, and in lipid oxidative modification in diabetes (Wolff, 1993). It was reported that the level of lipid peroxidation and activities of antioxidant enzymes were increased in streptozotocin-induced diabetic rats (Aliciguzel, Ozen, Aslan, Karayalcin, 2003; Yilmaz, Uz, Yucel, Altuntas, \& Ozcelik, 2004). Diabetic conditions were shown to improve through maintaining the antioxidative defense of diabetic liver or reducing the peroxidative stress-induced hepatic damage (Baydas, Canatan, Turkoglu, 2002; Yilmaz et al., 2004). Based on results of this study, the traditional claim of BM in treating diabetes could be partly explained by its antioxidant activities, which are able to scavenge free radicals and act against free radical damage to cell membranes through reducing the level of lipid peroxides.

\subsection{Total flavonoid and phenol contents}

Fig. 6 shows the total flavonoid and phenol contents of different wild $\mathrm{BM}$ extracts. Compared to BM-EtOH $(44.0 \mathrm{mg} / \mathrm{g}$ for total flavonoids and $68.8 \mathrm{mg} / \mathrm{g}$ for total phenols), $\mathrm{BM}-\mathrm{H}_{2} \mathrm{O}$ appeared to have a higher concentration of total flavonoids $(62.0 \mathrm{mg} / \mathrm{g})$ but a lower content in phenolic compounds $(51.6 \mathrm{mg} / \mathrm{g})$.

Plant tissues contain a wide variety of compounds with antioxidant activity. Phenolic compounds (flavonoids and phenolic acids), nitrogen compounds (alkaloids, chlorophyll derivatives, amino acids and amines), carotenoids, lignans and terpenes were reported to possess antioxidative activity in suppressing the initiation or propagation of the chain reactions (Hall \& Cuppett, 1997). Flavonoids and phenolic compounds are the main antioxidative compounds of fruits and vegetables (Huang, Tan, Shen, \& Lu, 1998). In this study, BM extracts showed antioxidant activities, however, the magnitude of antioxidative potency varies with the type of extracts. This could be due to the

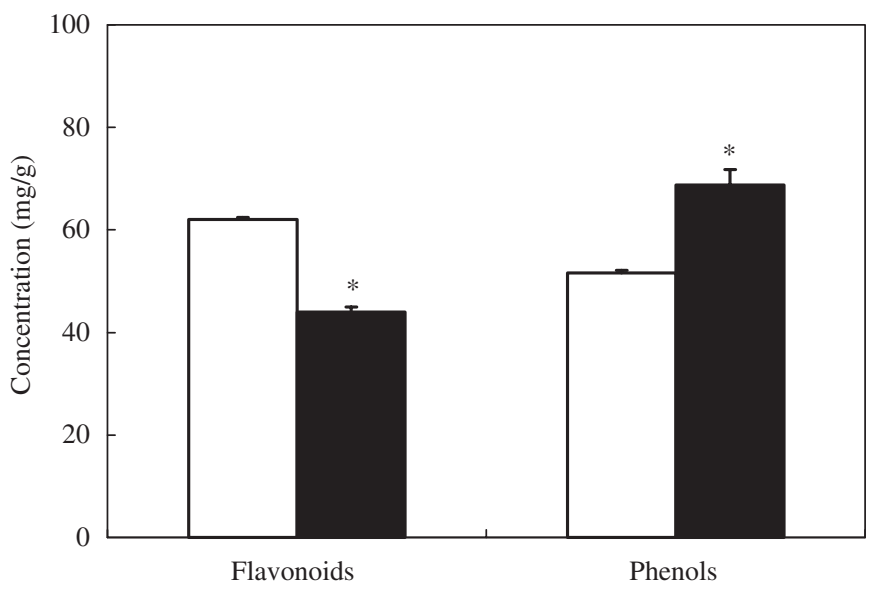

Fig. 6. Total flavonoid and phenol contents of different wild bitter melon extracts (aqueous: $\mathrm{BM}-\mathrm{H}_{2} \mathrm{O}$ and ethanol: $\mathrm{BM}-\mathrm{EtOH}$ ). The asterisk indicates a significant difference between $\mathrm{BM}-\mathrm{H}_{2} \mathrm{O}$ and $\mathrm{BM}-\mathrm{EtOH}$ extracts at $P<0.05$ as analyzed by Student's $t$-test. $\square, \mathrm{BM}-\mathrm{H}_{2} \mathrm{O}$; $\mathbf{\square}$, BM-EtOH. 
different in concentrations and type of antioxidative compounds present in these extracts.

\section{Conclusion}

In conclusion, the present study has demonstrated that BM extracts possess potent antioxidant and free radical scavenging activities, of which could be derived from compounds such as flavonoids and phenols. These antioxidant activities could have contributed, at least partly, to the therapeutic benefits of the certain traditional claims of wild $\mathrm{BM}$. In view of the potential use of BM in the health food industry, therefore its therapeutic benefits and bioactive compounds warrant for further investigations.

\section{References}

Aliciguzel, Y., Ozen, I., Aslan, M., \& Karayalcin, U. (2003). Activities of xanthine oxidoreductase and antioxidant enzymes in different tissues of diabetes rats. Journal of Laboratory and Clinical Medicine, 142, 172-177.

Bartold, P. M., Wiebkin, O. W., \& Thonard, J. C. (1984). The effect of oxygen-derived free radicals on gingival proteoglycans and hyaluronic acid. The Journal of Periodontology, 19, 390-400.

Baydas, G., Canatan, H., \& Turkoglu, A. (2002). Comparative analysis of the protective effects of melatonin and vitamin E on streptozocininduced diabetes mellitus. Journal of Pineal Research, 32, 225-230.

Baynes, J. W., \& Thorpe, S. R. (1999). Role of oxidative stress in diabetic complications: A new perspective on an old paradigm. Diabetes, 48 , $1-9$.

Blois, M. S. (1958). Antioxidant determinations by the use of stable free radical. Nature, 26, 1199-1200.

Ceriello, A. (2000). Oxidative stress and glycemic regulation. Metabolism, 49, 27-29.

Chang, W. C., Lee, E. L., \& Ng, L. T. (2006). Factors influencing the 2,2diphenyl-1-picrylhydrazyl (DPPH) radical scavenging assay in the natural product analysis. Tajen Journal, 28, 17-36.

Chang, W. S., Chang, Y. H., Lu, F. J., \& Chiang, H. C. (1994). Inhibitory effects of phenolics on xanthine oxidase. Anticancer Research, 14, 501-506.

Chao, C. Y., \& Huang, C. J. (2003). Bitter gourd (Momordica charantia) extract activates peroxisome proliferators-activated receptors and upregulates the expression of the acyl-CoA oxidase gene in H4IIEC3 hepatoma cells. Journal of Biomedical Science, 10, 782-791.

Cheng, H. Y., Lin, T. C., Yu, K. H., Yang, C. M., \& Lin, C. C. (2003). Antioxidant and free radical scavenging activities of Terminalia chebula. Biological \& Pharmaceutical Bulletin, 26, 1331-1335.

Chiu, N. Y., \& Chang, K. H. (1995). The illustrated medicinal plants of Taiwan, vol. 4. Taipei, Taiwan: SMC Publishing Inc. p. 213.

Cliffe, S., Fawer, M. S., Maier, G., Takata, K., \& Ritter, G. (1994). Enzyme assays for the phenolic content of natural juices. Journal of Agricultural and Food Chemistry, 42, 1824-1828.

Compori, M. (1985). Lipid peroxidation and cellular damage in toxic liver injury. Laboratory Investigation, 53, 599-620.

Dinis, T. C. P., Madeira, V. C. M., \& Almeida, L. M. (1994). Action of phenolic derivates (acetoaminopehn, salycilate and 5-aminosalycilate) as inhibitors of membrane lipid peroxidation and as peroxyl radical scavengers. Archives of Biochemistry and Biophysics, 315, 161-169.

Gordon, M. H. (1990). The mechanism of antioxidant action in vitro. In B. J. F. Hudson (Ed.), Food antioxidants (pp. 1-18). London/New York: Elsevier.

Grover, J. K., \& Yadav, S. P. (2004). Pharmacological actions and potential uses of Momordica charantia: A review. Journal of Ethnopharmacology, 93, 123-132.
Hall, C. A., \& Cuppett, S. L. (1997). Activities of natural antioxidants. In O. I. Aruoma, \& S. L. Cuppett (Eds.), Antioxidant methodology in vivo and in vitro concepts (pp. 2-29). Champaign, IL, USA: AOCS Press.

Halliwell, B. (1997). Antioxidants and human disease: A general introduction. Nutrition Review, 55, S44-S52.

Halliwell, B., \& Gutteridge, J. M. (1984). Lipid peroxidation, oxygen radicals, cell damage, and antioxidant therapy. Lancet, 23, 1396-1397.

Harinantenaina, L., Tanaka, M., Takaoka, S., Oda, M., Mogami, O., Uchida, M., et al. (2006). Momordica charantia constituents and antidiabetic screening of the isolated major compounds. Chemical \& Pharmaceutical Bulletin, 54, 1017-1021.

Hatono, T., Edamatsu, R., Hiramatsu, M., Mori, A., Fujita, Y., Yasuhara, T., et al. (1989). Effects of the interaction of tannins with co-existing substances. VI. Effects of tannins and related polyphenols on superoxide anion radical and on DPPH radical. Chemical \& Pharmaceutical Bulletin, 37, 2016-2021.

Hearse, D. J., Manning, A. S., Downey, J. M., \& Yellon, D. M. (1986). Xanthine oxidase: A critical mediator of myocardial injury during ischemia and reperfusion? Acta Physiologica Scandinavica, 548, 65-78.

Hochstein, P., \& Atallah, A. S. (1988). The nature of oxidants and antioxidant systems in the inhibition of mutation and cancer. Mutation Research, 202, 363-375.

Huang, Y., Tan, A., Shen, Y., \& Lu, J. (1998). Scavenging effect of total flavonoids of Lycium barbarum $L$ on active oxygen radicals and inhibitory effects on heat output from L 1210 cells. Wei Sheng Yen Chiu, 27, 109-111.

Ichikawa, H., \& Konishi, T. (2002). In vitro antioxidant potentials of traditional Chinese medicine, Shengmai San and their relation to in vivo protective effect on cerebral oxidative damage in rats. Biological \& Pharmaceutical Bulletin, 25, 898-903.

Kimura, Y., Okuda, T., Hatono, T., Agata, I., \& Arichi, S. (1985). Effects of extracts of leaves of Artemisia species and caffeic acid and chlorogenic acid on lipid metabolic injury in rats fed peroxidized oil. Chemical \& Pharmaceutical Bulletin, 33, 2028-2034.

Kimuya, K., Kubo, M., Tani, T., Arich, S., \& Okuda, H. (1981). Studies on Scutellariae radix. IV. Effects on lipid peroxidation in rat liver. Chemical \& Pharmaceutical Bulletin, 29, 2610-2617.

Kornbrust, D. J., \& Mavis, R. D. (1980). The effect of paraquat on microsomal lipid peroxidation in vitro and in vivo. Toxicology and Applied Pharmacology, 53, 323-332.

Kubow, S. (1990). Toxicity of dietary lipid peroxidation products. Trends Food Science \& Technology, 1, 67-71.

Lako, J., Trenerry, V. C., Wahlqvist, M., Wattanapenpaiboon, N., Sotheeswaran, S., \& Premier, R. (2007). Phytochemical flavonols, carotenoids and the antioxidant properties of a wide selection of Fijian fruit, vegetables and other readily available foods. Food Chemistry, 101, 1727-1741.

Lee-Huang, S., Huang, P. L., Chen, H. C., Bourinbaiar, A., Huang, H. I., \& Kuang, H. F. (1995). Anti-HIV and anti-tumor activities of recombinant MAP30 from bitter melon. Gene, 161, 151-156.

Lin, C. C., Hsu, Y. F., \& Lin, T. C. (2001). Antioxidant and free radical scavenging effects of the tannins of Terminalia catappa L. Anticancer Research, 21, 237-243.

Lin, C. C., Ng, L. T., Yang, J. J., \& Hsu, Y. F. (2004). Antioxidant activity of extracts of Peh-Hue-Juwa-Chi-Cao in a cell free system. The American Journal of Chinese Medicine, 32, 339-349.

Lowry, O. H., Rosebrough, N. J., Farr, A. L., \& Randall, R. J. (1951). Protein measurement with the folin phenol reagent. Journal of Biological Chemistry, 193, 265-275.

McCord, J. M., \& Fridovich, I. (1969). Superoxide dismutase: An enzymic function for erythrocuprein (hemocaprein). Journal of Biological Chemistry, 244, 6049-6055.

Raj, S. K., Khan, M. S., Singh, R., Kumari, B., \& Prakash, D. (2005). Occurrence of yellow mosaic geminiviral disease on bitter gourd (Momordica charantia) and its impact on phytochemical contents. International Journal of Food Science and Nutrition, 56, 185-192.

Slater, T. F. (1984). Free-radical mechanisms in tissue injury. Biochemical Journal, 222, 1-15. 
Varani, J., Fligiel, S. E. G. ., Till, G. O., Kunkel, R. G. ., Ryan, V. S., \& Ward, P. A. (1985). Pulmonary endothelial cell killing by human neutrophils: possible involvement of hydroxyl radical. Laboratory Investigation, 53, 656-663.

Wolff, S. P. (1993). Diabetes mellitus and free radicals. Free radicals, transition metals and oxidative stress in the aethiology of diabetes mellitus and complications. British Medical Bulletin, 49, 642-652.

Yamaguchi, F., Ariga, T., Yoshimira, Y., \& Nakazawa, H. (2000). Antioxidant and anti-glycation of carcinol from Garcinia indica fruit rind. Journal of Agricultural and Food Chemistry, 48, 180-185.
Yilmaz, R. H., Uz, E., Yucel, N., Altuntas, I., \& Ozcelik, N. (2004). Protective effect of caffeic acid phenethyl ester (CAPE) on lipid peroxidation and antioxidation enzymes in diabetic rat liver. Journal of Biochemical and Molecular Toxicology, 18, 234-238.

Yoshiyuki, K., Michinori, K., Tadato, T., Shigeru, A., \& Hiromichi, O. (1981). Studies on Scutellariae radix. IV. Effects on lipid peroxidation in rat liver. Chemical \& Pharmaceutical Bulletin, 29, 2610-2617.

Zou, Y. P., Lu, Y. H., \& Wei, D. Z. (2004). Antioxidant activity of a flavonoid-rich extract of Hypericum perforatum L. in vitro. Journal of Agricultural and Food Chemistry, 52, 5032-5039. 